medRxiv preprint doi: https://doi.org/10.1101/2021.04.18.21255521; this version posted April 20, 2021. The copyright holder for this preprint

(which was not certified by peer review) is the author/funder, who has granted medRxiv a license to display the preprint in perpetuity.

It is made available under a CC-BY-NC-ND 4.0 International license .

\title{
Health effects of European colonization: An investigation of skeletal remains from 19th to early 20th century migrant settlers in South Australia
}

Angela Gurr ${ }^{1,2^{*}}$, Jaliya Kumaratilake ${ }^{1,2}$, Alan Henry Brook ${ }^{3,4}$, Stella Ioannou ${ }^{1}$, F. Donald Pate ${ }^{5}$, Maciej Henneberg ${ }^{1,2,5,6}$

1. Biological Anthropology and Comparative Anatomy Research Unit, Adelaide Medical School, University of Adelaide, Adelaide, South Australia

2. Discipline of Anatomy and Pathology, Adelaide Medical School, University of Adelaide, Adelaide, South Australia

3. School of Dentistry, University of Adelaide, Adelaide, South Australia

4. Institute of Dentistry, Queen Mary, University of London, London, United Kingdom

5. Archaeology, Flinders University, Adelaide, South Australia

6. Institute of Evolutionary Medicine, University of Zurich, Zurich, Switzerland

Key words: Colonial Migration, Health, Economic Status, Metabolic Deficiencies, Adelaide

Running title: Skeletal manifestations of health deficiencies in Colonial South Australia

*Corresponding author: Email: angela.gurr@ adelaide.edu.au (AG)

\section{Abstract}

Nineteenth century medical understanding of human metabolism was limited, therefore, the incidence of metabolic deficiencies was not fully recorded. In addition, the transition from agricultural based mode of life to the industrial one significantly changed the pattern of these metabolic deficiencies. They were further altered by colonisation of distant continents. Palaeopathological study of skeletal remains from the early industrialised colonial era allowed light to be shed on the metabolic stresses produced by this new mode of life. Aims of this study were to investigate manifestations of disease in skeletal remains from 65 (20 adults, 45 sub-adults) migrant settlers buried in the "free ground" of St Mary's Anglican Church Cemetery (1847 to 1927). An area allocated for burials paid for by the South Australian Government. Skeletal manifestations were determined and interpreted in terms of their multiple aetiologies. Findings were compared with those published for two $19^{\text {th }}$ century British samples. Skeletal manifestations, commonly related to metabolic deficiencies, were observed. Areas of abnormal porosity of bone cortices were seen in 9 adults and 12 subadults, flaring of metaphyses was seen in one sub-adult, flaring of costochondral junctions of the ribs was seen in one sub-adult. Porous lesions of orbital roof bones (Types 3 to 5) were seen on three sub-adults. Micro-CT scans of tooth samples located interglobular dentine in three individuals. Comparison of St Mary's findings with St Martins, Birmingham, and St Peter's, Wolverhampton, UK, showed more individuals from St Mary's had areas of abnormal porosity of bone cortices possibly related to vitamin C deficiency. However, St Mary's sample displayed fewer changes attributable to vitamin D deficiency as expected in a country with greater UV irradiation. This indicates that, although the early industrialisation produced metabolic stresses, change of the environment through colonisation of new continents altered the distribution of metabolic deficiencies. 
medRxiv preprint doi: https://doi.org/10.1101/2021.04.18.21255521; this version posted April 20, 2021. The copyright holder for this preprint (which was not certified by peer review) is the author/funder, who has granted medRxiv a license to display the preprint in perpetuity.

\author{
It is made available under a CC-BY-NC-ND 4.0 International license.
}


medRxiv preprint doi: https://doi.org/10.1101/2021.04.18.21255521; this version posted April 20, 2021. The copyright holder for this preprint

\section{Abstract}

2 Nineteenth century medical understanding of human metabolism was limited, therefore, the

3 incidence of metabolic deficiencies was not fully recorded. In addition, the transition from

4 agricultural based mode of life to the industrial one significantly changed the pattern of these

5 metabolic deficiencies. They were further altered by colonisation of distant continents.

6 Palaeopathological study of skeletal remains from the early industrialised colonial era

7 allowed light to be shed on the metabolic stresses produced by this new mode of life. Aims of

8 this study were to investigate manifestations of disease in skeletal remains from 65 (20

9 adults, 45 sub-adults) migrant settlers buried in the "free ground" of St Mary's Anglican

10 Church Cemetery (1847 to 1927). An area allocated for burials paid for by the South

11 Australian Government. Skeletal manifestations were determined and interpreted in terms of

12 their multiple aetiologies. Findings were compared with those published for two $19^{\text {th }}$ century

13 British samples. Skeletal manifestations, commonly related to metabolic deficiencies, were

14 observed. Areas of abnormal porosity of bone cortices were seen in 9 adults and 12 sub-

15 adults, flaring of metaphyses was seen in one sub-adult, flaring of costochondral junctions of

16 the ribs was seen in one sub-adult. Porous lesions of orbital roof bones (Types 3 to 5) were

17 seen on three sub-adults. Micro-CT scans of tooth samples located interglobular dentine in

18 three individuals. Comparison of St Mary's findings with St Martins, Birmingham, and St

19 Peter's, Wolverhampton, UK, showed more individuals from St Mary's had areas of

20 abnormal porosity of bone cortices possibly related to vitamin C deficiency. However, St

21 Mary's sample displayed fewer changes attributable to vitamin D deficiency as expected in a country with greater UV irradiation. This indicates that, although the early industrialisation produced metabolic stresses, change of the environment through colonisation of new continents altered the distribution of metabolic deficiencies. 
medRxiv preprint doi: https://doi.org/10.1101/2021.04.18.21255521; this version posted April 20, 2021. The copyright holder for this preprint

(which was not certified by peer review) is the author/funder, who has granted medRxiv a license to display the preprint in perpetuity.

It is made available under a CC-BY-NC-ND 4.0 International license .

\section{Introduction}

35

Although medical knowledge and medical literature had been well developed in the $19^{\text {th }}$ century, they did not include the modern understanding of human metabolism and thus could not record the occurrence of metabolic deficiencies. Pattern of these deficiencies had been significantly changed by the transition from agricultural based mode of life to the industrial one and further altered by colonisation of far away continents. Palaeopathological study of skeletal remains from the early industrialisation colonial era allows to shed light on the metabolic stresses produced by the new mode of life.

Industrialisation of Britain in the $19^{\text {th }}$ century altered the landscape, the economy, and the lives of many people. This had health consequences. The expansion of urban centres of manufacture offered opportunities for employment, however, the majority of cities lacked the infrastructure to cope with the increase in the population size due to a migration of workers. Many people had to live under overcrowded and unsanitary conditions, where the water supplies could be contaminated [1-3]. These conditions, long hours of working inside factories powered by coal fired engines, and diets lacking in essential nutrients contributed to the poor health of the working classes in a way different from traditional agricultural communities [2, 4-7].

Rapid development of urban centres, also affected the traditional small industries in rural regions of Britain. The inability to compete with the low production costs of commercial items in large factories caused an increase in rural unemployement [8-10]. In addition, importation of large quantities of raw materials to feed the urban industries at cheaper prices, such as iron, copper and tin ores, caused the down turn of regional mining industries $[9,10]$. 
medRxiv preprint doi: https://doi.org/10.1101/2021.04.18.21255521; this version posted April 20, 2021. The copyright holder for this preprint

59 Poor harvests and the rapid spread of potato blight, further affected farmers $[8,11]$. The net

60 outcome was economic hardship in regional rural areas of the United Kingdom.

61

62 The British Government planned to reduce over-crowding in industrial cities, unemployment

63 and economic hardships in regional areas by resettling people into the new colony of South

64 Australia $[12,13]$. The South Australian Act (1834) allowed the sale of land in the proposed

65 settlement to individuals who would establish primary industries such as farming, mining and

66 manufacturing [13-15]. Thus, emigration to South Australia was extensively advertised in

67 Britain [16]. The vast size and natural environment of South Australia for farming, its

68 Mediterranean climate and rich minerals could have attracted people to migrate to the new

69 colony who wished to create and develop their own opportunies, rather than going to an

70 established colony such as in North America [16]. The development of the new Australian

71 colony required builders, mechanics, agricultural labourers, and miners [17]. A high number

72 of migrants to South Australia came from the counties of Cornwall, Devon, Dorset and

73 Somerset, followed by Lancashire, Middlesex, Staffordshire and Warwickshire [16, 18, 19].

75 Migrants who could not afford the cost of the voyage to South Australia could apply for an

76 "assisted passage". Migration via this route was regulated by The Colonial Land and

77 Emigration Commission (CLEC), whose agents selected equal numbers of male and female

78 healthy young people of "good character" $[16,17,20]$. The policy was designed to maintain a

79 regular supply of skilled workers to landowners, new industries and to advance the

80 development of new settlements $[16,17,20]$. The assisted passage to the new colony was

81 funded by the British Government and The South Australian Company. Additional financial

82 help, for individuals with an assisted passage, could be applied for from local charitable

83 organisations. This money covered the cost of transport to the port of departure, the 
medRxiv preprint doi: https://doi.org/10.1101/2021.04.18.21255521; this version posted April 20, 2021. The copyright holder for this preprint

(which was not certified by peer review) is the author/funder, who has granted medRxiv a license to display the preprint in perpetuity.

It is made available under a CC-BY-NC-ND 4.0 International license .

84 compulsory deposit required for bedding, utensils and a set of "all weather" clothing for the

85 long voyage $[16,20]$.

86

87 In total, 186,054 indivduals migrated to South Australia between 1836 and 1900 from the

88 United Kingdom. The government "assisted passage" was received by 123,039 (66\%)

89 migrants [17]. The above mentioned selection criteria were not applied to individuals who

90 paid the full costs of their passage and had adequate funds to support themselves in the

91 colony.

92

93 The health of migrants on arrival in South Australia was of a high priority for the British

94 Government. Therefore, the Colonial Land and Emigration Commission monitored

95 conditions on board ships. Each ship had a Surgeon Superintendent, who was accountable for

96 the health and wellbeing of all passengers [16, 20,21].

97

98 Political disagreements within the new South Australian Government delayed the surveying

99 of land for migrant settlements and the development of supporting infrastructure [12]. This

100 affected the initial establishment of farms, food production, industrial enterprises, and

101 permanent housing for migrants. These issues also delayed the development of the economy,

102 caused unemployment and led to the removal of the first Governor, Captain John Hindmarsh.

103 The second Governor, Lieutenant Colonel George Gawler, was appointed by the British

104 Government in $1838[19,22]$. Governor Gawler had a proactive approach to leadership and

105 commissioned multiple infrastructure projects to rapidly develop the colony [22, 23].

106 Payment of the expenditure associated with these developments was rejected by the British

107 Government, who were unwilling to cover the high costs, and recalled Governor Gawler to

108 London in $1841[19,24]$. 
medRxiv preprint doi: https://doi.org/10.1101/2021.04.18.21255521; this version posted April 20, 2021. The copyright holder for this preprint

(which was not certified by peer review) is the author/funder, who has granted medRxiv a license to display the preprint in perpetuity.

It is made available under a CC-BY-NC-ND 4.0 International license .

109 The third South Australian Governor, Captain George Grey, was appointed the same year,

110 and the colony faced its first economic depression $[19,25]$. The lack of funds to continue

111 public works meant Governor Grey faced retrenchment between 1841 and 1845 . He

112 redirected the majority of the unemployed workforce to agricultural industries $[12,19]$. The

113 eventual outcome was an increase of agricultural goods, particularly wheat and animal

114 products and the establishment of export industries to other Australian colonies and Britain

$115[12,15]$.

116

117 Climatic conditions of South Australia, high summer temperatures and limited rainfall, often

118 resulted in periods of drought and poor harvests. These conditions could have contributed to

119 the poor economic growth and the unemployment experienced during the establishment of

120 the colony. Throughout this period, the life of many settlers was harsh, particularly those who

121 were unemployed and had to depend on charitable organisations and the government for their

122 survival [23]. Government of South Australia State Records [26], indicate that 446 sick and

123 destitute people received help in the form of food rations from the Emigration Department in

$1241839-1840$. This number increased to 904 persons for the period of $1840-1841$ [23]. In

1251843 , an act was passed relating to the care of the needy and this was followed by the

126 establishment of the Destitute Board in 1849. This board offered support to the elderly,

127 chronically infirm, and some widows, and initiated the construction of a 'Destitute Asylum'

128 in the city of Adelaide during the 1850s [23, 27, 28].

130 The Destitute Asylum was modelled on the British workhouse system [27], with strict

131 regulations, such as complusory wearing of uniforms for "inmates", and severe penalties if

132 regulations were not followed [23, 29]. This "indoor" relief at the Destitute Asylum was the

133 last resort for individuals who had to prove that they had no relatives able to support them 
medRxiv preprint doi: https://doi.org/10.1101/2021.04.18.21255521; this version posted April 20, 2021. The copyright holder for this preprint

(which was not certified by peer review) is the author/funder, who has granted medRxiv a license to display the preprint in perpetuity.

It is made available under a CC-BY-NC-ND 4.0 International license.

134 [29]. Expectant mothers with no other support were also admitted to the asylum for up to six

135 months and received "Lying-In-Home" relief [23, 29]. Furthermore, "deserted" women with

136 children, who had no means of support were allowed admision to the asylum [29].

137 Individuals, who still had their own accommodation but no other support, were given weekly

138 food rations and fire wood as "outdoor" relief from the Ayslum [29]. People who lived in

139 rural areas either had to travel long distances into the city of Adelaide to receive "outdoor"

140 relief or cope as best they could within their own community.

141

142 Other burdens that early migrant settlers had to face were the spread of infectious diseases

143 such as diphtheria, typhoid, typhus fever, and tuberculosis [30-34]. In addition, individuals

144 who could not afford the cost of local medical services would have been badly affected, as

145 the only public hospital was located at the city of Adelaide [35, 36]. People, who lived in

146 rural areas may also have had limited access to health services [36]. Chronic conditions such

147 as metabolic deficiencies, together with some of the above-mentioned diseases, can cause

148 changes in the bone morphology. A number of skeletal abnormalities, for example, abnormal

149 porosity in the cortex of bones, bending of long bones, enlargement and flaring of

150 costochondral junctions of ribs, and porous lesions of the bones of the orbital roof, have

151 previously been interpreted as signs of metabolic deficiencies, [37-41]. However, these

152 skeletal lesions can be produced by a range of aetiologies [42-44].

153

154 St Marys-on-the-Sturt was an early rural migrant settlement, which was established from the

155 late 1830's [45]. It was a small village located eight kilometres south of the city of Adelaide

156 (Fig.1A to C). The majority of the settlers were of British origin, who wished to establish an

157 Anglican Church (St Mary's) in the village. They also allocated the land surrounding the

158 church for a cemetery (Fig.1D), with the first burial in 1847 [46]. The cemetery had a section 
medRxiv preprint doi: https://doi.org/10.1101/2021.04.18.21255521; this version posted April 20, 2021. The copyright holder for this preprint

(which was not certified by peer review) is the author/funder, who has granted medRxiv a license to display the preprint in perpetuity.

It is made available under a CC-BY-NC-ND 4.0 International license .

159 referred to as the "free ground", where individuals or their families, who had no funds to

160 support the cost of a burial were interred. The burials in the "free ground" were unmarked

161 and the costs were paid for by the Government of South Australia [23, 47, 48]. This section

162 of the cemetery was located at the rear of the church building (Fig. 1D) and was in use from

1631847 to $1927 .[45]$

166 Fig 1. Location maps. A: Location of South Australia in relation to other Australian States and

167 Territories. B: Location of the city of Adelaide, capital of South Australia. C: Location of St

168 Mary's Anglican Church Cemetery in relation to the city of Adelaide. D: St Mary's Church and

169 associated cemetery. The hatched rectangle shows the "free ground" area which is located at the

170 rear of the church building.

172 The focus of this study was to investigate abnormalities seen in the skeletal remains

173 excavated from the "free ground" area of St Mary's Anglican Church Cemetery and

174 understand the lifeways of these people. This study cannot ascertain the socioeconomic status

175 of each individual buried in the "free ground" of St Mary's Cemetery from the observed

176 skeletal manifestations. However, the location of their burial suggests they had faced

177 economic hardship around the time of death. Parish records of the St Mary's Church

178 Cemetery, list occupations of individuals who were buried in the "free ground" area, as,

179 among others, cabinet maker, blacksmith, schoolteacher, and accountant. Some of these

180 people had skilled trades and were considered to be more than just labourers. The probability

181 is that this was a mixed group, mainly people who were from a working class.

182

183 Aims and Objectives:

184 The aims of this study were to 
medRxiv preprint doi: https://doi.org/10.1101/2021.04.18.21255521; this version posted April 20, 2021. The copyright holder for this preprint (which was not certified by peer review) is the author/funder, who has granted medRxiv a license to display the preprint in perpetuity.

It is made available under a CC-BY-NC-ND 4.0 International license .

185 i) Investigate manifestations of disease in the skeletal remains of a group of settlers

186 buried in the "free ground" area of St Mary's Anglican Church Cemetery, South

$187 \quad$ Australia, from 1847 to 1927.

188 ii) Compare the findings of the St Mary's samples with those published for skeletal

189 samples from two $19^{\text {th }}$ century British communities.

190 iii) Compare the number of individuals buried during the study period (1847 to 1927) in

191 other sections of St Mary's Cemetery to the number of people and the percentage of

192 burials at the "free ground" area to understand the economic context of life in the new

193 colony.

194

195 Material and Methods

196

197 Skeletal remains of 65 individuals (20 adults and 45 sub-adults), excavated from the "free

198 ground" section of St Mary's Anglican Church Cemetery, South Road, Adelaide, South

199 Australia (Site code: SMB - St Mary's Burial) in 2000, were available for examination. No

200 other sections of the cemetery were excavated. These individuals were buried in the "free

201 ground" between 1847 and 1927 in unmarked graves, which prevented identification of

202 individuals. Sex and age at death were estimated immediately post excavation using the

203 standard physical anthropological methods [47].

204

205 The skeletal remains are part of an archaeological collection; therefore, no destructive

206 analysis was permitted.

207

208

209

210 Each skeleton was arranged in the anatomical position, and an inventory of the bones was

211 prepared as described by Buikstra et al.[49] and Mitchell and Brickley [50]. Skeletal 
medRxiv preprint doi: https://doi.org/10.1101/2021.04.18.21255521; this version posted April 20, 2021. The copyright holder for this preprint

212 manifestations related to metabolic deficiencies were recorded as described by Brickley[51],

213 Brickley and Ives [37], Heron [52], Mays et al., [39], Ortner et al., [41, 53], and Ortner \&

214 Ericksen,[40] (Table 1 and Table 2). Results that are presented in Table 1 are shown as the

215 number of individuals with the observed manifestation (-n-) over the total number (-N-) of

216 individuals with the bone available for observation $(\mathrm{n} / \mathrm{N})$.

218 Porous lesions on the bones of the orbital roof were quantitated using the scoring system

219 described by Stuart-Macadam [54], i.e., Type 1 - "capillary-like impression on bone”, Type

220 2- "scattered fine foramina", Type 3 to 5 -ranged from "large and small isolated foramina to

221 outgrowths from trabecular bone that extended to the surface of the outer table.

222 Investigation of the internal structure of tooth samples for interglobular dentine (IGD) was

223 part of the study. The traditional methods used for such investigations were histological

224 techniques and these require sectioning of the tooth sample. Consequently, a non-destructive

225 method introduced to detect IGD, using X-Ray Computed Tomography (micro-CT) was

226 used. Cost of this method allowed only a selection of tooth samples from St Mary's skeletal

227 collection to be investigated.

One tooth each from 19 individuals was selected. The individuals were selected from a broad age range ( 2 years to $60+$ years of age). Collected teeth included two permanent incisors, three permanent canines, three permanent premolars, nine permanent first molars, and two

232 primary molars, as the same tooth type was not available from each individual. Each tooth

233 was scanned using the Bruker SkyScan 1276 Micro-CT scanner at Adelaide Microscopy, The

234 University of Adelaide [55]. The scanner was set at source voltage: $100 \mathrm{kV}$, source current

$235200 \mu \mathrm{A}$, camera binning: 4032 x 2688, filter: aluminium and copper, pixel size: $9.0 \mu \mathrm{m}$.

236 Tooth sample from SMB 63, was additionally scanned using the pixel size was $5.21 \mu \mathrm{m}$. 
medRxiv preprint doi: https://doi.org/10.1101/2021.04.18.21255521; this version posted April 20, 2021. The copyright holder for this preprint (which was not certified by peer review) is the author/funder, who has granted medRxiv a license to display the preprint in perpetuity.

It is made available under a CC-BY-NC-ND 4.0 International license .

237 Micro-CT scan datasets were reconstructed into a visual image using NRecon, a volumetric

238 reconstruction software. These reconstructed scan data sets were viewed as either two-

239 dimensional (2D) or three-dimensional (3D) images using Dataviewer, a 'volume rendering'

240 software and Avizo 9 software [56]. The 2D and 3D images were analysed to identify

241 mineralisation defects in the teeth. Dentine defects seen on the micro-CT scans were scored,

242 as described by Colombo et al. [57] and Veselka et al. [58].

244 St Mary's Parish Records and Cemetery Survey:

245 Parish records from St Mary's Anglican Church, South Australia, in relation to potential

246 burials in the "free ground" area of the cemetery from 1847 to 1927 were used. These

247 documents recorded the burial location of some individuals, but not all [47]. The parish

248 records also provided an approximate date of burials and the occupation for some individuals.

249 Calculations for Figure 3 used the data from these records.

250 The date of death and approximate date of burial for individuals who paid for their burial in

251 provenanced graves, i.e., in the "leased ground" of the main section of the cemetery with a

252 memorial marker/gravestone (Fig. 1D), was recorded during a survey of the St Mary's

253 Cemetery.

Comparison of observed metabolic deficiencies from St Mary's samples with those of British samples:

257

258 Findings of the St Mary's samples were compared with those published for two $19^{\text {th }}$ century

259 to early $20^{\text {th }}$ century British skeletal samples. One sample was from St Martin's-in-the-

260 Bullring Church, Birmingham, England $(\mathrm{N}=406)[37,39,59]$, where the majority of burials

261 were between 1810 and 1864, with declining numbers of individuals interred until 1915 [59].

262 St Martin's was located in an industrial city where many individuals from the working

263 classes might have been buried, this sample was considered appropriate as many individuals 
medRxiv preprint doi: https://doi.org/10.1101/2021.04.18.21255521; this version posted April 20, 2021. The copyright holder for this preprint (which was not certified by peer review) is the author/funder, who has granted medRxiv a license to display the preprint in perpetuity.

It is made available under a CC-BY-NC-ND 4.0 International license .

264 interred in the "free ground" of St Mary's, or their families if they were infants, were likely

265 from a similar socioeconomic working-class background at the time of death.

266 The published results for a second Bristish skeletal sample were from a section of St Peter's

267 Collegiate Church, Wolverhampton, England, referred to as the "overflow burial ground"

268 (1819 to approximately 1900) [60,61]. Wolverhampton was originally a market town with a

269 mix of agriculture and small industries. The industrial development of local mining activities,

270 during the $19^{\text {th }}$ century, contributed to the increase in population size [60]. Published findings

271 from St Peter's skeletal samples were considered an appropriate comparison sample to the St

272 Mary's sample as some individuals in St Peter's sample could have been miners, and it is

273 known that many migrants to the new colony were from mining communities $[16,17,62$,

274 63].

275

276

277

\section{Results}

278

279

\section{Demography:}

280 Estimated age at death range and estimation of sex for the skeletal samples from St Mary's

281 'free ground" are shown in Figure 2. Among the 45 sub-adults in this sample, 36 were under two years of age.

Fig 2. Demography. Distribution of the excavated St Mary's "free ground" skeletal samples 286 by age at death and sex [47].

\section{Parish Records and Cemetery Survey Data:}

289 In the main cemetery area, surrounding St Mary's Church, a total of 227 people were buried

290 in "provenanced" graves between 1847 and 1927. The comparison of the number of

291 individuals recorded in parish records as possibly buried in the "free ground" area of St 
medRxiv preprint doi: https://doi.org/10.1101/2021.04.18.21255521; this version posted April 20, 2021. The copyright holder for this preprint

(which was not certified by peer review) is the author/funder, who has granted medRxiv a license to display the preprint in perpetuity.

It is made available under a CC-BY-NC-ND 4.0 International license .

292 Mary's Cemetery ( $n=195)$, with the number of provenanced burials $(n=227)$, by the decade of

293 burial are presented in Figure 3.

294

295 Fig 3. St Mary's Parish Records: A Comparison of the number of people possibly buried in

296 the "free ground" area $(n=195)$ with those buried in provenanced graves $(n=227)$ of $S t$

297 Mary's cemetery, according to parish records [47], by decades of burial. Red dashed line

298 indicates the percentage of burials in the "free ground" area of the cemetery.

299

300

301 Summary of observed skeletal manifestations:

302 Pathological manifestations relating to health deficiencies, possibly metabolic, were

303 identified on the skeletal remains of some individuals buried at St Mary's "free ground" area.

304 They are presented below:

305

306 Abnormal porosity in the bone cortex:

307 Nine adults and 12 sub-adults were observed with at least one area of abnormal porosity in

308 the cortical parts of following bones: maxillae - the posterior surface, alveolar process, and

309 palatine processes (Fig. 4); medial surfaces of the coronoid process of the mandible; and the

310 greater wing of the sphenoid. One infant, SMB 56, (approximately 6-9 months of age), in

311 addition to the above bones, showed areas of abnormal porosity in cortices of the lateral and

312 basilar portion of the occipital bone, scapulae, ribs, vertebral arches, ilia, and the extremities

313 of long bones. The prevalences of abnormal porosity are presented in Table 1.

Fig 4. SMB 56. Palate, inferior view, showing areas of abnormal porosity that extended throughout the alveolar process of the maxillae. 
medRxiv preprint doi: https://doi.org/10.1101/2021.04.18.21255521; this version posted April 20, 2021. The copyright holder for this preprint (which was not certified by peer review) is the author/funder, who has granted medRxiv a license to display the preprint in perpetuity.

It is made available under a CC-BY-NC-ND 4.0 International license.

321 Table 1. Prevalence of observed skeletal manifestations associated with health deficiencies observed in different bones of the skeletons of individuals from St Mary's sample.

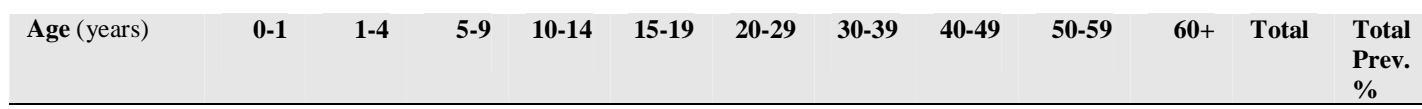

\begin{tabular}{|c|c|c|c|c|c|c|c|c|c|c|c|c|}
\hline $\begin{array}{l}\text { Abnormal } \\
\text { porosity in } \\
\text { the cortex of } \\
\text { bones listed } \\
\text { below: }\end{array}$ & & & & & & & & & & & & \\
\hline $\begin{array}{l}\text { Maxillae: } \\
\text { poserior } \\
\text { surface }\end{array}$ & $1 / 5$ & $2 / 11$ & $0 / 2$ & $0 / 2$ & $0 / 1$ & $0 / 1$ & $0 / 2$ & $0 / 3$ & $0 / 2$ & $0 / 1$ & $3 / 30$ & 10 \\
\hline $\begin{array}{l}\text { Palatine } \\
\text { proceses }\end{array}$ & $1 / 4$ & $0 / 13$ & $0 / 2$ & $0 / 3$ & $0 / 1$ & $0 / 1$ & $0 / 3$ & $1 / 5$ & $1 / 6$ & $0 / 1$ & $3 / 39$ & 8 \\
\hline $\begin{array}{l}\text { Alveolar } \\
\text { process }\end{array}$ & $2 / 3$ & $4 / 13$ & $1 / 2$ & $1 / 2$ & $0 / 1$ & $0 / 1$ & $1 / 3$ & $0 / 5$ & $0 / 6$ & $0 / 1$ & $9 / 37$ & 24 \\
\hline $\begin{array}{l}\text { Mandible: } \\
\text { Coronoid } \\
\text { process }\end{array}$ & $1 / 9$ & $0 / 13$ & $0 / 2$ & $0 / 3$ & $0 / 1$ & $0 / 1$ & $0 / 3$ & $1 / 5$ & $0 / 6$ & $0 / 1$ & $2 / 44$ & 5 \\
\hline $\begin{array}{l}\text { Alveolar } \\
\text { process }\end{array}$ & $1 / 9$ & $0 / 15$ & $0 / 2$ & $1 / 3$ & $0 / 1$ & $0 / 1$ & $0 / 3$ & $0 / 5$ & $0 / 7$ & $0 / 2$ & $3 / 48$ & 6 \\
\hline $\begin{array}{l}\text { Greater wing } \\
\text { of the } \\
\text { sphenoid } \\
\text { bones }\end{array}$ & $0 / 3$ & $1 / 6$ & $1 / 3$ & $1 / 2$ & $0 / 1$ & $0 / 1$ & $0 / 3$ & $0 / 5$ & $0 / 6$ & $0 / 2$ & $3 / 32$ & 9 \\
\hline $\begin{array}{l}\text { Other skeletal } \\
\text { changes to } \\
\text { bones listed } \\
\text { below: }\end{array}$ & & & & & & & & & & & & \\
\hline $\begin{array}{l}\text { Ribs: } \\
\text { Enlargement } \\
\text { costochondral } \\
\text { junctions }\end{array}$ & $1 / 4$ & $0 / 5$ & $0 / 1$ & $0 / 2$ & $0 / 1$ & $0 / 1$ & $0 / 3$ & $0 / 3$ & $0 / 2$ & $0 / 0$ & $1 / 22$ & 5 \\
\hline $\begin{array}{l}\text { Long bones: } \\
\text { Flaring-distal } \\
\text { metaphysis }\end{array}$ & $0 / 13$ & $1 / 14$ & $0 / 3$ & $0 / 1$ & $0 / 1$ & $0 / 1$ & $0 / 3$ & $0 / 5$ & $0 / 7$ & $0 / 1$ & $1 / 49$ & 2 \\
\hline $\begin{array}{l}\text { Orbital roofs } \\
\text { porous lesions } \\
\text { (any Type) }\end{array}$ & $0 / 7$ & $2 / 14$ & $1 / 3$ & $3 / 3$ & $1 / 1$ & $0 / 1$ & $0 / 3$ & $0 / 5$ & $2 / 8$ & $0 / 2$ & $9 / 46$ & 20 \\
\hline $\begin{array}{l}\text { Orbital roofs } \\
\text { porous lesions } \\
\text { (Types } 3 \text { or } 4 \text { ) }\end{array}$ & $0 / 7$ & $1 / 14$ & $1 / 3$ & $1 / 3$ & $0 / 1$ & $0 / 1$ & $0 / 3$ & $0 / 5$ & $0 / 6$ & $0 / 2$ & $3 / 46$ & 7 \\
\hline
\end{tabular}

Note. Results presented as the number of individuals with the observed sign (-n-) over the total number $(-\mathrm{N}-)$ of individuals with the bone available for observation $(\mathrm{n} / \mathrm{N})$, with age groups of the individuals.

\section{Enlargement and flaring of the costochondral junctions of ribs:}

One infant, SMB 56, had enlargement and flaring of the costochondral junctions of ribs

335 (Table 1). 
medRxiv preprint doi: https://doi.org/10.1101/2021.04.18.21255521; this version posted April 20, 2021. The copyright holder for this preprint (which was not certified by peer review) is the author/funder, who has granted medRxiv a license to display the preprint in perpetuity.

It is made available under a CC-BY-NC-ND 4.0 International license .

\section{Enlargement and flaring of the metaphyses:}

338 One sub-adult, SMB 8, showed flaring and enlargement of the distal metaphyses of the

339 femora (Table 1).

340

\section{Porous lesions on the bones of the orbital roof:}

342 Three sub-adults, SMB 4A, SMB 19 and SMB 28, age range from 4 years to 13 years,

343 showed porous lesions on the bones of the orbital roof of Types 3 and 4 [64], which are often

344 referred to as 'cribra orbitalia'. The lesions of SMB 28 were composed of small and large

345 pores on the right and left orbital roof respectively (Fig. 5). The pores on the right orbital roof

346 seemed to penetrate the cortical bone, while those on the left appeared to be exposed

347 trabecular bone (Fig. 5). This sub-adult also displayed areas of abnormal porosity in the

348 cortex of the greater wing of the sphenoid bones bilaterally (Table 1). The prevalence rate of

349 porous lesions seen on orbital roof bones in St Mary's sample are presented in Table 1.

351

352

353

354

355

356

357

358

359

360

361

362

363
Fig 5. SMB 28. Lesions on the orbital roof bones. Red arrow indicates small pores in the right cortical bone. Blue arrow indicates possible exposed trabecular bone on the left.

\section{Dentine - Interglobular dentine (IGD)}

Lesions in the internal structure of the tooth seen in micro-CT scans were areas of unmineralised collagen matrix in the dentine. Such lesions have been described as interglobular dentine $[65,66]$. Tooth samples from three individuals, SMB 6 ( 40 to 45 years of age), SMB $63(\sim 55$ to $60+$ years of age), and SMB 70 ( 7 to 12 years of age) (Fig. 6) were seen with areas of IGD. Individual SMB 70 had suffered from congenital syphilis and had been treated with mercury [67]. Therefore, this sub-adult was excluded from this part of the study as the toxic treatment could have resulted in IGD. The tooth sample from SMB 
medRxiv preprint doi: https://doi.org/10.1101/2021.04.18.21255521; this version posted April 20, 2021. The copyright holder for this preprint (which was not certified by peer review) is the author/funder, who has granted medRxiv a license to display the preprint in perpetuity.

It is made available under a CC-BY-NC-ND 4.0 International license .

36463 (a permanent lower lateral incisor) was selected for further investigation using a higher

365 resolution of the micro-CT scanner (pixel size: $5.21 \mu \mathrm{m}$ ). This revealed areas of IGD in three

366 separate incremental linear arrangements, one of the areas of IGD was observed opposite an

367 external enamel hypoplastic defect (Fig. 6). The crown of this tooth type commences

368 mineralisation at approximately 30 weeks of intrauterine life $( \pm 1$ month $)$ and completes at

369 approximately 3.5 years $( \pm 1$ year $)$.

370

371

372

373

374

375

376

377

378

379

380

Sub-adults from the St Mary's sample who showed two or more macroscopic pathological

381 manifestations of a health deficiency are listed in Table 2.

382

383

384

385

386

387

388

389

390

391

392

393

Fig 6. Micro-CT images. SMB 63. (a) Lower lateral permanent incisor with a fracture in crown. (b) Transverse slice: at the level of IGD in the crown. (c) Transverse slice: arrows show four areas of IGD. (d) Transverse slice: arrows show three areas of IGD, image was angled to show location of IGD in three concentric layers. (e) White arrow shows IGD (internal) opposite an enamel hypoplastic defect red arrow (external).

(1)

4

85

87

388

389


medRxiv preprint doi: https://doi.org/10.1101/2021.04.18.21255521; this version posted April 20, 2021. The copyright holder for this preprint (which was not certified by peer review) is the author/funder, who has granted medRxiv a license to display the preprint in perpetuity.

It is made available under a CC-BY-NC-ND 4.0 International license .

Table 2. St Mary's sub-adult samples, with their age range, showing two or more macroscopic pathological manifestation of a health deficiency.

\begin{tabular}{|c|c|c|c|c|c|c|}
\hline Burial Code & SMB 27B & SMB 28 & SMB 51 & SMB 56 & SMB 58 & SMB 70 \\
\hline $\begin{array}{l}\text { Age range at } \\
\text { death (years) }\end{array}$ & 0 to 5 & 10 to 15 & 10 to 15 & 0 to 5 & 0 to 5 & 7 to 12 \\
\hline $\begin{array}{l}\text { Greater wing of } \\
\text { the sphenoid } \\
\text { bones } \dagger\end{array}$ & -- & $\mathbf{P}$ & -- & -- & $\mathbf{A}$ & $\mathbf{P}$ \\
\hline $\begin{array}{l}\text { Zygomatic bones: } \\
\text { internal surface } \dagger\end{array}$ & -- & -- & -- & -- & $\mathbf{P}$ & -- \\
\hline $\begin{array}{l}\text { Maxillae: } \\
\text { posterior surface } \dagger\end{array}$ & $\mathbf{A}$ & $\mathbf{A}$ & -- & $\mathbf{P}$ & $\mathbf{P}$ & $\mathbf{A}$ \\
\hline $\begin{array}{l}\text { Maxillae: } \\
\text { palatine process } \dagger\end{array}$ & $\mathbf{A}$ & $\mathbf{A}$ & $\mathbf{A}$ & $\mathbf{P}$ & $\mathbf{A}$ & $\mathbf{A}$ \\
\hline $\begin{array}{l}\text { Maxillae: } \\
\text { alveolar process } \dagger\end{array}$ & $\mathbf{P}$ & $\mathbf{P}$ & -- & $\mathbf{P}$ & $\mathbf{P}$ & $\mathbf{P}$ \\
\hline $\begin{array}{l}\text { Mandible: } \\
\text { coronoid process } \\
\text { medial surface } \dagger\end{array}$ & $\mathbf{A}$ & $\mathbf{A}$ & $\overline{\mathbf{A}}$ & $\mathbf{P}$ & $\mathbf{A}$ & -- \\
\hline $\begin{array}{l}\text { Mandible: } \\
\text { alveolar process } \dagger\end{array}$ & $\mathbf{A}$ & $\mathbf{A}$ & $\mathbf{P}$ & $\mathbf{P}$ & $\mathbf{P}$ & -- \\
\hline $\begin{array}{l}\text { Orbital roofs: } \dagger \\
\text { Type: (number } \\
\text { given) }\end{array}$ & P 1 & $\mathbf{P} 4$ & P 1 & -- & $\mathbf{A}$ & $\mathbf{A}$ \\
\hline $\begin{array}{l}\text { Scapulae: } \dagger \\
\text { supraspinous or } \\
\text { infraspinous areas }\end{array}$ & -- & $\mathbf{A}$ & $\mathbf{A}$ & $\mathbf{P}$ & $\mathbf{A}$ & $\mathbf{P}$ \\
\hline Pelvic bones $\dagger$ & $\mathbf{A}$ & $\mathbf{A}$ & $\mathbf{A}$ & $\mathbf{P}$ & $\mathbf{A}$ & $\mathbf{P}$ \\
\hline $\begin{array}{l}\text { Ribs: enlargement } \\
\text { of costochondral } \\
\text { junctions }\end{array}$ & -- & $\mathbf{A}$ & $\mathbf{A}$ & $\mathbf{P}$ & $\mathbf{A}$ & -- \\
\hline $\begin{array}{l}\text { Long bones: } \\
\text { Flaring of distal } \\
\text { metaphyses }\end{array}$ & -- & $\mathbf{A}$ & -- & $\mathbf{A}$ & $\mathbf{A}$ & $\mathbf{A}$ \\
\hline
\end{tabular}

Key: $\dagger=$ Areas of abnormal porosity (lesions) in the bone cortices observed

Findings of St Mary's samples and demographic profiles were compared with published results for $19^{\text {th }}$ century skeletal samples buried at St Martin's-in-the-Bullring Church,

406 Birmingham, England, and St Peter's Collegiate Church, (overflow burial ground),

407 Wolverhampton, England. A comparison of the number and percentage of adults and sub408 adults from each sample is presented in Table 3. 
410 Table 3. Demographic profiles of St Mary's, St Martins and St Peter's cemeteries

\begin{tabular}{|c|c|c|c|c|c|}
\hline Cemetery & $\begin{array}{c}\text { Total } \\
\text { Sample Size } \\
\text { N = }\end{array}$ & \multicolumn{2}{|c|}{ Adults } & \multicolumn{2}{c|}{ Sub- adults } \\
\cline { 3 - 6 } & & number & $\%$ & number & $\%$ \\
\hline $\begin{array}{c}\text { St Mary's } \\
\text { (SA) }\end{array}$ & 65 & 20 & 31 & 45 & 69 \\
\hline $\begin{array}{c}\text { St Martin's } \\
\text { (UK) }\end{array}$ & 406 & 242 & 60 & 164 & 40 \\
\hline $\begin{array}{c}\text { St Peter's } \\
\text { (UK) }\end{array}$ & 150 & 92 & 61 & 58 & 39 \\
\hline
\end{tabular}

418

419 A comparison of the macroscopic observed skeletal manifestations among the sub-adult 420 samples from the three cemeteries is presented in Figure 7.

Fig 7. Comparison of the three cemeteries. Skeletal manifestations observed in the subadults samples from St Mary's, St Martin's and St Peter's Cemeteries and the number of individuals affected.

428 Abnormal porosity in the bone cortex:

429 Sub-adults from St Martin's and St Peter's Cemeteries were observed with areas of abnormal

430 porosity in the cortices of the following bones: infra orbital area, maxillae, hard palate,

431 coronoid processes of the mandible, orbital, parietal and occipital bones, and scapulae [37,

$43259,61]$. St Mary's had more sub-adults with this manifestation (abnormal porosity in the

433 bone cortex) compared to St Martin's and St Peter's samples (Fig. 7). Nine adults from the St

434 Mary's sample were also seen with one area of abnormal porosity in the cortices of bones. 
medRxiv preprint doi: https://doi.org/10.1101/2021.04.18.21255521; this version posted April 20, 2021. The copyright holder for this preprint

(which was not certified by peer review) is the author/funder, who has granted medRxiv a license to display the preprint in perpetuity.

It is made available under a CC-BY-NC-ND 4.0 International license .

435 However, this skeletal manifestation was not observed in any adults from St Martin's or St

436 Peter's samples [37, 59, 61].

437

438 Bending /bowing distortion of long bones:

439 This skeletal abnormality was seen only among sub-adults of St Martins and St Peter's

440 cemeteries (Fig. 7) [39, 59, 61]. Furthermore, no adults from either of the three cemeteries

441 were seen with this skeletal abnormality.

442

443 Enlargement and flaring of metaphyses:

444 St Martin's had a greater number of sub-adults with flaring of metaphyses than St Mary's and

445 St Peter's sub-adult samples (Fig. 7) [39, 59, 61]. No adults from the three cemeteries were

446 seen with this skeletal manifestation.

447

448 Porous lesions on the bones of the orbital roof:

449 The scores for this specific skeletal manifestation from St Martin's samples cannot be

450 compared between St Mary's and St Peter's samples as they were not available separately for

451 the Types 3 and 4 . However, published results for this cemetery do state that 18 sub-adults

452 and 17 adults were observed with "varying degrees" of porous lesions on the bones of the

453 orbital roof (Fig. 7). [59].

454

455

456 Discussion

457 The "free ground" area of St Mary's Anglican Church Cemetery was allocated for the

458 interment of people from the community of St Marys-on-the-Sturt, South Australia, who did

459 not have the funds to cover the cost of a burial. According to the parish records from St 
medRxiv preprint doi: https://doi.org/10.1101/2021.04.18.21255521; this version posted April 20, 2021. The copyright holder for this preprint

460 Mary's Church, for the decades: 1840 s, 1850 s, and the $1860 \mathrm{~s} ; 80 \%, 80 \%$, and $83 \%$

461 respectively, of the total number of people buried at the St Mary's Cemetery were interred at

462 the "free ground" area (Fig. 3). This indicates that for approximately 30 years, over $80 \%$ of

463 the individuals who were buried at the cemetery or their families, could not pay for the

464 burials. This was the period of establishment of the new colony, during which time, the

465 colony experienced economic recession and had a high unemployment rate $[12,19]$.

466 Therefore, a good percentage of the early settlers at St Marys-on-the-Sturt region may not

467 have had regular employment to earn an adequate amount of money to support themselves

468 and save for the latter part of their life. They may have had to depend on charitable

469 organisations or the Government for their survival. This early economic hardship in the

470 colony is reflected in the need for relief from the Destitute Asylum for many living in or near

471 the city of Adelaide. Introduction of an old age pension, after the turn of the $20^{\text {th }}$ century,

472 reduced the need for the Destitute Asylum [29].

473

474 Thirty six out of the 45 subadults $(80 \%)$ buried at the "free ground" area were less than two

475 years of age (Fig. 2). St Mary's Church parish records list some infants as "unbaptised - no

476 service" [47]. It is possible that some of these infants were stillborn or died a short time after

477 birth. Such infants could have contributed to the high percentage of sub-adults in the St

478 Mary's sample. There were no official regulations regarding the location of burial of a still

479 born infant in the early colony or the requirement to register the birth of a still born child

480 until $1936[48,68]$. Burial practices of perinates, excavated at the $19^{\text {th }}$ century Parramatta

481 Convict Hospital in NSW, Australia, showed they were afforded very little respect or care

$482[69]$.

483 
medRxiv preprint doi: https://doi.org/10.1101/2021.04.18.21255521; this version posted April 20, 2021. The copyright holder for this preprint

484 The percentage of burials at the St Mary's "free ground" area began to reduce from the $4^{\text {th }}$

485 decade after the establishment of cemetery and reached $8 \%$ of the total burials in the decade

486 of the 1920's (Fig. 3). This demonstrates that there was a gradual improvement of the

487 economic status of some individuals who lived at St Marys-on-the-Sturt region. This local

488 improvement could have followed the national trend of economic development of the colony

489 of South Australia. This also shows that the majority of the skeletons studied here come from

490 the earlier period in the life of the colony and practically characterise its health status during

491 the 19th century, rather than reaching into the $20^{\text {th }}$ century.

492

493 Bones of the skeleton are a dynamic tissue and undergo remodelling during life, possibly

494 according to the variations in forces acting on them during life. Therefore, disease

495 manifestations seen in skeletal remains, particularly in bone cortices, occurred during the last

496 remodelling before death [70, 71].

497

498 Abnormal porous lesions on bone cortices result from defective calcification of the bone

499 matrix [40, 41, 51, 72]. Vitamin C and vitamin D deficiencies affect collagen synthesis [73,

500 74], and affect mineralisation [65, 75, 76], respectively. Abnormal porosity of the bone

501 cortices seen in archaeological skeletal samples could be produced by both processes. In

502 addition, porous lesions seen on the bones of the orbit roof could be caused by an anaemia.

503 Anaemia has often been associated with a deficiency of iron. [54, 77, 78].When haemoglobin

504 becomes inadequate, due to the lack of iron in the body, the red marrow compensates by the

505 overproduction of red blood cells and thus produces a proliferation of red bone marrow. This

506 can result in an expansion of the trabecular bone, amongst other pathological processes,

507 between the tables of the skull [78]. In extreme conditions, the surface bone cortex of the 
medRxiv preprint doi: https://doi.org/10.1101/2021.04.18.21255521; this version posted April 20, 2021. The copyright holder for this preprint

(which was not certified by peer review) is the author/funder, who has granted medRxiv a license to display the preprint in perpetuity.

It is made available under a CC-BY-NC-ND 4.0 International license .

508 orbital roof may thin out and expose the underlying trabecular bone, which could appear as

509 porous lesions.

510

511 Abnormal porous lesions that were seen in the cortical bone of 9 adults and 12 sub-adults of

512 St Mary's skeletal collection could have resulted from either vitamin C or D deficiencies

513 (Table 1). Presence of abnormal porosities in the bone cortices of the greater wing of the

514 sphenoid, bilaterally, has been considered in the past as pathognomonic of vitamin C

515 deficiency [40, 41]. Three of St Mary's sub-adults would fit into this category (Table 1).

516 However, Brickley [38] has suggested that abnormal porous lesions should be present on

517 more than one bone/location of the skeleton to be considered as a diagnosis of vitamin C

518 deficiency. Accordingly, six of St Mary's sub-adults including two of the three sub-adults

519 mentioned above with lesions on the sphenoid bones, would fit into the "multiple" lesions

520 category (Table 2). Furthermore, one sub-adult in this category had flaring of the

521 costochondral junctions of the ribs. This skeletal manifestation could be attributed to either

522 vitamin C or vitamin D deficiencies (Brickley 2008). The remaining nine adults and six sub-

523 adults only had one area of abnormal porosity on one location of the skeleton. Therefore,

524 could not be considered as individuals with a deficiency of vitamin $\mathrm{C}$. The areas of abnormal

525 porosity seen on these individuals could represent a manifestations of vitamin D deficiency,

$526[38,39]$. However, none of them had any other of the common signs of vitamin D deficiency,

527 such as bowing and bending distortions of the long bones [38, 39, 79]. One sub-adult did

528 have flaring of the distal metaphyses of the femora but without any other pathological

529 manifestation observed elsewhere in the skeleton, this sub-adult could not be included in

530 either of the above vitamin C or D categories (Table 1).

531 
medRxiv preprint doi: https://doi.org/10.1101/2021.04.18.21255521; this version posted April 20, 2021. The copyright holder for this preprint

532 Three of St Mary's sub-adults had porous lesions on the bones of the orbital roof of Types 3

533 and 4 [54]. These "types" of lesion have been considered as an indicator of anaemia. This

534 could result from a dietary deficiency of iron, and/or vitamin B12, malabsorption of iron

535 from the gut due to chronic diseases or gastrointestinal and blood parasites, chronic blood

536 loss and/or genetic conditions or a combination of these conditions [42, 54, 78, 80-83]. One

537 sub-adult, SMB 28, also had areas of abnormal porosity on the greater wings of the sphenoid

538 bones, (bilaterally). Therefore, it is likely that this individual could have had a co-occurence

539 of anaemia and vitamin C deficiency (Brickley, 2016; Fain, 2005; Ortner et al., 2001; Ortner

540 \& Ericksen, 1997). Vitamin C enchances the absorption of iron from the gut, so a deficiency

541 of vitamin C in SMB 28 could have intensified any anaemia present.

543 Tooth development commences in utero and continues until approximately 21 to 23 years of

544 age $[84,85]$. In dentine, after the development of the tooth, the remodelling process is

545 minimal compared to bone $[65,66,86]$, therefore, any pathological changes (lesions) would

546 remain for the rest of the life. The areas of IGD, seen in the two adults from St Mary's

547 sample, would have resulted from health insults that caused an interuption of the

548 mineralisation process in dentine during the development of the tooth. It is unknown if these

549 individuals spent their younger lives in the UK or South Australia, indicating that the IGD

550 could have occurred before migration. The three areas of IGD seen in SMB 63 could have

551 resulted from three separate episodes of health insults during their childhood. Furthermore,

552 one of the health insults that caused an area of IGD may have also resulted in the enamel

553 hypoplastic defect (Fig. 6.e) [87-89]. The formation of IGD has been widely related to

554 vitamin D deficiency [57, 58, 90-93]. However, neither of the two St Mary's adults showed

555 any other skeletal pathological manifastations, including porous lesions or bending

556 abnormalties of long bones. 
medRxiv preprint doi: https://doi.org/10.1101/2021.04.18.21255521; this version posted April 20, 2021. The copyright holder for this preprint (which was not certified by peer review) is the author/funder, who has granted medRxiv a license to display the preprint in perpetuity.

It is made available under a CC-BY-NC-ND 4.0 International license .

558 Comparison of St Mary's “free ground" skeletal samples with those of St Martin's and 559 St Peter's samples in Britain:

560

561 The working-class background of some of the people buried at the "free ground" area of St

562 Mary's Cemetery could be similar to those published for St Martin's and St Peter's

563 cemeteries in Britain $[59,61]$. However, the demographic profile of the St Mary's sample is

564 somewhat different from those of the British samples, as the majority of St Mary's sample is

565 made up of sub-adults (Fig. 2). Most of these sub-adults were under two years of age and

566 according to St Mary's Church parish records, one of the common causes of death was

567 gastrointestinal conditions [47]. Most of the sub-adult deaths could have resulted from

568 dehydration resulting from diarrhoea or vomiting, as emergency access to medical help

569 would have been difficult due to the location of the public hospital in the city of Adelaide,

570 some $8 \mathrm{~km}$ away from St Marys-on-the-Sturt.

571 Areas of abnormal porosity in the cortices of bones, that could be considered as a deficiency

572 of vitamin C, were seen in sub-adults from St Mary's, St Martin's and St Peter's skeletal

573 samples $[37,61]$. The prevalence of such lesions was higher among the subadults from the St

574 Mary's sample (13\%) compared to that from St Martin's (4 \%) and St Peter's samples (2 \%).

575 The lower prevalence of this manifestation (probable vitamin $\mathrm{C}$ deficiency) among the sub-

576 adults of the British samples could be due to the availability of fresh fruits and vegetables in

577 Birmingham and Wolverhampton. The initial difficulties and delays in establishing farms and

578 the production of foods, during the first decades of the development of South Australia,

579 indicates that foods particularly those rich in vitamin C, may not have been readily available.

580 This was especially true if there was a scarcity of water $[13,94]$. Some of the sub-adults

581 affected by this deficiency, from all three of the cemeteries, could have been breastfed infants

$582[37,61]$. Therefore, their deficienecy could have resulted from a dietary deficiency of the 
medRxiv preprint doi: https://doi.org/10.1101/2021.04.18.21255521; this version posted April 20, 2021. The copyright holder for this preprint

583 mother $[51,53,95]$. Infants could also have been affected by the feeding and weaning

584 practices of the period [96-98]. Elevated nitrogen isotope values $(+1.7 \%$ ) observed in

585 skeletal remains of some infants from the St Mary's sample [99], relative to those of adult

586 females in the same sample, suggested that breastmilk was a principal source of diet for

587 infants. However, these findings do not indicate whether the child received adequate amounts

588 of milk during breast feeding.

589

590 The number of individuals with the manifestation of enlargement and flaring of the

591 costochondral junctions of ribs and flaring of the metaphyses of long bones was higher

592 among St Martin's and St Peter's sub-adult samples compared to those of St Mary's samples

593 (Fig. 7) [39, 61]. The manifestation of bending distortions of long bones was only seen

594 among sub-adults of St Martin's and St Peter's samples, and not observed in any of sub-adult

595 samples from St Mary's (Fig. 7). Skeletal remains of adults from the three cemeteries were

596 free of the above-mentioned manifestations. These skeletal abnormalities have been linked to

597 a chronic deficiency of vitamin D [39, 61]. Among the St Mary's subadults the lower

598 incidence of the manifestations linked to vitamin D deficiency (Fig. 7) could be due to the

599 abundance of sunlight (UV rays) in South Australia.

600

601 St Martin's had the higher number of subadults with porous lesions in the bones of the orbital

602 roof (Fig. 7) [59]. However, the scores for these porous lesions, as described by Stuart-

603 Macadam [64], were not available (Brickley, personal communication, 2018). This lack of

604 data made it difficult to compare St Martin's to St Mary's and St Peter's samples in this

605 aspect (Fig 7). Nevertheless, it is clear that many of St Martin's sub-adults had experienced

606 chronic systemic health insults before death [78].

607 
medRxiv preprint doi: https://doi.org/10.1101/2021.04.18.21255521; this version posted April 20, 2021. The copyright holder for this preprint

(which was not certified by peer review) is the author/funder, who has granted medRxiv a license to display the preprint in perpetuity.

It is made available under a CC-BY-NC-ND 4.0 International license .

608 A comparison between the South Australian and British samples assisted in the evaluation of

609 the level of manifestations related to health deficiencies observed in the migrant settlers

610 buried in the "free ground" area of St Mary's Anglican Church Cemetery. It also contributes

611 to a wider picture of life and death in the mid- $19^{\text {th }}$ to early $20^{\text {th }}$ century community of St

612 Marys-on-the-Sturt.

613

614

\section{Conclusion}

616 Skeletal manifestations observed on individuals excavated from the "free ground" area of St

617 Mary's Anglican Church Cemetery, South Australia, show that St Mary's sub-adults had a

618 higher incidence of abnormal porosity on the bone cortex compared to the British samples.

619 Furthermore, skeletal abnormalities such as bending distortion of long bones were more

620 common among the British samples compared to St Mary's samples. This indicates that,

621 although the early industrialisation produced metabolic stresses, change of the environment

622 through colonisation of new continents altered the distribution of metabolic deficiencies.

624 The new colony of South Australia, with its natural resources and Mediterranean climate

625 could have offered many early British migrant the hope of a better life. However,

626 unpreparedness of the Government of the new colony for settlement of the early migrants,

627 and the refusal of the British Government to bear the cost of the establishment of the new

628 infrastructure, led to an economic recession and mass unemployment. These caused marked

629 hardship to the migrants. Subsequently, the timely action of the third governor of the colony

630 helped the South Australian economy to recover. The pattern of burials at the "free ground"

631 area of St Mary's Cemetery from 1847 to 1927 showed the evolution of the economic status

632 of some migrants who had settled at St Marys-on-the-Sturt. Furthermore, this pattern of 
medRxiv preprint doi: https://doi.org/10.1101/2021.04.18.21255521; this version posted April 20, 2021. The copyright holder for this preprint (which was not certified by peer review) is the author/funder, who has granted medRxiv a license to display the preprint in perpetuity. It is made available under a CC-BY-NC-ND 4.0 International license.

633 burials in the St Mary's Cemetery was a good reflection of the wider economic development

634 of the colony.

635

636

637

638

639

640

641

642

643

644

645

646

647

648

649

650

651

652

653

654

655

656

657

658

659

660

661 
medRxiv preprint doi: https://doi.org/10.1101/2021.04.18.21255521; this version posted April 20, 2021. The copyright holder for this preprint (which was not certified by peer review) is the author/funder, who has granted medRxiv a license to display the preprint in perpetuity.

It is made available under a CC-BY-NC-ND 4.0 International license.

662

663

664 The authors have no conflicts of interest to declare.

665

666

667 This research received no specific grant from any funding agency, commercial entity or not-

668 for-profit organization.

669

670

671 The data that support the findings of this study are available in the supporting information or 672 from the corresponding author upon request.

673

674 
medRxiv preprint doi: https://doi.org/10.1101/2021.04.18.21255521; this version posted April 20, 2021. The copyright holder for this preprint (which was not certified by peer review) is the author/funder, who has granted medRxiv a license to display the preprint in perpetuity.

It is made available under a CC-BY-NC-ND 4.0 International license.

675

676

\section{Professional and Funding Acknowledgements}

678 The authors acknowledge The University of Adelaide including the Faculty of Health and

679 Medical Sciences Honours and PhD Scholarships for AG. Fr. William Deng, St Mary’s

680 Anglican Church and the Department of Archaeology, Flinders University, for allowed

681 access to the St Mary's skeletal sample. The authors acknowledge the facilities, and the

682 scientific and technical assistance, of the Australian Microscopy \& Microanalysis Research

683 Facility at the Adelaide Microscopy, University of Adelaide, especially Ruth Williams for

684 her assistance with micro-CT scanning and post processing software.

685

686

687

688

689

690

691

692

693

694

695

696

697

698

699

700

701 


\section{References}

1. Betsinger TK, DeWitte SN. The Bioarchaeology of Urbanization The Biological, Demographic, and Social Consequences of Living in Cities. 1st ed. 2020. ed. Switerland: Springer International Publishing; 2020.

2. Szreter S. Economic Growth, Disruption, Deprivation, Disease, and Death: On the Importance of the Politics of Public Health for Development. Population and Development Review. 1997;23(4):693-728. doi: 10.2307/2137377.

3. Szreter S. Urbanization, Mortality, and the Standard of Living Debate. New Estimates of the Expectation of Life at Birth in Nineteenth-Century British Cities.In: Health and Wealth. Boydell \& Brewer; 2005. p. 165.

4. Ashworth WJ. The industrial revolution the State, knowledge and global trade. London : Bloomsbury Academic; 2017.

5. Brimblecombe P. London air pollution, 1500-1900. Atmospheric Environment (1967). 1977;11(12):1157-62. doi: 10.1016/0004-6981(77)90091-9.

6. Dewitte SN, Hughes-Morey G, Bekvalac J, Karsten J. Wealth, health and frailty in industrial-era. London. Annals of Human Biology. 2016;43(3):241-54. doi: 10.3109/03014460.2015.1020873.

7. Newman SL, Gowland RL. Dedicated Followers of Fashion? Bioarchaeological Perspectives on Socio $\square$ Economic Status, Inequality, and Health in Urban Children from the Industrial Revolution (18th-19th C), England. International Journal of Osteoarchaeology. 2017;27(2):217-29. doi: 10.1002/oa.2531.

8. Lokan J. From Cornish Miner to Farmer in Nineteenth-Century South Australia: A Case Study. Cornish studies. 2008;16(1):48-77. doi: 10.1386/corn.16.1.48_1.

9. Payton P. Cornish Emigration in Response to Changes in the International Copper Market in 1860s. Exeter, UK: University of Exeter; 1995.

10. Rowe J. Cornwall in the age of the Industrial Revolution. Liverpool: Liverpool University Press; 1953.

11. Lidwell-Durnin J. Cultivating famine: data, experimentation and food security, 17951848. The British journal for the history of science. 2020;53(2):159-81. doi: 10.1017/S0007087420000199.

12. Price AG. The foundation and settlement of South Australia, 1829-1945 : a study of the colonization movement, based on the records of the South Australian Government and on other authoritative documents. Adelaide: Libraries Board of South Australia; 1973.

13. Wilkinson GB. South Australia, its advantages and its resources : being a description of that colony, and a manual of information for emigrants / by George Blakiston Wilkinson. London : J. Murray; 1848.

14. Nance C. The South Australian social experiment 1836-71 : a study of some of the aspects of South Australia's early social development. Adelaide Flinders University of South Australia 1977.

15. Wilkinson GB. The working man's handbook to South Australia, with advice to the farmer, and detailed information for the several class of labourers and artisans. London: Murray; 1849.

16. Haines R. Emigration and the labouring poor : Australian recruitment in Britain and Ireland, 1831-60. New York : Macmillan; St. Martin's Press; 1997.

17. Haines R. Nineteenth century government assisted immigrants from the United Kingdom to Australia : schemes, regulations and arrivals, 1831-1900 and some vital statistics 1834-1860. South. Australia: Flinders University of South Australia; 1995. 
18. Lawrence S, Davies P. Cornish tin-streamers and the Australian gold rush: technology transfer in alluvial mining. Post-medieval archaeology. 2015;49(1):99-113. doi: 10.1179/0079423615Z.00000000073.

19. Pike D. Paradise of dissent : South Australia 1829-1857 / Douglas Pike. 2nd ed. Melbourne : Melbourne University Press; 1967.

20. Haines R. Life and death in the age of sail : the passage to Australia. Sydney: UNSW Press; 2003.

21. Haines R. Medical Superintendence and Child Health on Government-Assisted Voyages to South Australia in the Nineteenth Century. Health and History. 2001;3(2):1-29. doi: 10.2307/40111403.

22. Gibbs RM. Under the Burning Sun: A history of colonial South Australia, 1836-1900. Adelaide: Southern Heritage; 2013.

23. Dickey B. Rations, residence, resources : a history of social welfare in South Australia since 1836, with contributions from Elaine Martin and Rod Oxenberry. Martin E, Oxenberry R, editors. Netley, S. Aust. : Wakefield Press; 1986.

24. Dare R. Paupers' rights: Governor Grey and the poor law in South Australia. Australian historical studies. 1992;25(99):220-43. doi: 10.1080/10314619208595908.

25. Jaensch D. The Flinders history of South Australia. Political history. Netley, S. Aust: Wakefield Press; 1986.

26. Government of South Australia SR. Alphabetical index to return of sick and destitute emigrants who have received relief from the emigration department 1993 [cited 2021 25.01]. Available from: https://archives.sa.gov.au/finding-information/discover-ourcollection/health-and-welfare/destitution-south-australia\#navbar.

27. Piddock S. "An Irregular and Inconvenient Pile of Buildings": The Destitute Asylum of Adelaide, South Australia and the English Workhouse. International Journal of Historical Archaeology. 2001;5(1):73-95. doi: 10.1023/A:1009597226492.

28. Piddock S. A Space of Their Own: The Archaeology of Nineteenth Century Lunatic Asylums in Britain, South Australia and Tasmania. Orser CE, editor. New York, NY: Springer 2007.

29. Geyer M. Behind the wall : the women of the destitute asylum Adelaide, 1852-1918. Adelaide, S. Aust: Axiom, in association with the Migration Museum; 1994.

30. The Adelaide Observer. Prevention of Infection from Typhus Fever. The Adelaide Observer. 1845 18.01.1845 (col. 2).

31. The South Australia Register. Pollution of the Torrens. The South Australian Register. 1873 16.12.1874.

32. The South Australia Register. Drinking Typhoid. The South Australian Register. 1898 17.02.1898;Sect. Register.

33. The South Australian Register. Summer Cholera-Its Causes. The South Australian Register, 1847 10.02.1847;Sect. Medicine and Surgery.

34. Woodruff P. Two million South Australians. Kent Town, S. Aust: Peacock Publications; 1984.

35. Forbes ILD. From Colonial Surgeon to Health Commission : the government provision of health services in South Australia, 1836-1995. Myrtle Bank, S. Aust: I.L.D. Forbes 1996.

36. Manning GH. A colonial experience, 1838-1910 : a woman's story of life in Adelaide, the District of Kensington and Norwood together with reminiscences of colonial life / Underdale, S. Aust. : Gillingham Printers; 2001.

37. Brickley M, Ives R. Skeletal manifestations of infantile scurvy. American Journal of Physical Anthropology. 2006;129(2):163-72. doi: 10.1002/ajpa.20265. 
800 38. Brickley M. The bioarchaeology of metabolic bone disease. 1st ed. Ives R, editor.

801

802

803

804

805

806

807

808

809

810

811

812

813

814

815

816

817

818

819

820

821

822

823

824

825

826

827

828

829

830

831

832

833

834

835

836

837

838

839

840

841

842

843

844

845

846

847

848

849

Amsterdam ; Boston: Amsterdam ; Boston : Elsevier/Academic Press; 2008.

39. Mays S, Brickley M, Ives R. Skeletal manifestations of rickets in infants and young children in a historic population from England. American Journal of Physical Anthropology. 2006;129(3):362-74. doi: 10.1002/ajpa.20292.

40. Ortner DJ, Ericksen MF. Bone changes in the human skull probably resulting from scurvy in infancy and childhood. International Journal of Osteoarchaeology. 1997;7(3):212-20. doi: 10.1002/(SICI)1099-1212(199705)7:3\&lt;212::AIDOA346\&gt;3.0.CO;2-5.

41. Ortner DJ, Kimmerle EH, Diez M. Probable evidence of scurvy in subadults from archeological sites in Peru. American Journal of Physical Anthropology. 1999;108(3):321. doi: 10.1002/(SICI)1096-8644(199903)108:3\&lt;321::AIDAJPA7\&gt;3.0.CO;2-7.

42. Brickley M. Cribra orbitalia and porotic hyperostosis: A biological approach to diagnosis. American journal of physical anthropology. 2018;167(4):896. doi: 10.1002/ajpa.23701.

43. Rivera F, Lahr. M, Beatriz. M. New evidence suggesting a dissociated etiology for cribra orbitalia and porotic hyperostosis. American Journal of Anthropology. 2017;164:79-96. doi: 10.17863/CAM.10366.

44. Wapler U, Crubézy E, Schultz M. Is cribra orbitalia synonymous with anemia? Analysis and interpretation of cranial pathology in Sudan. American Journal of Physical Anthropology. 2004;123(4):333-9. doi: 10.1002/ajpa.10321.

45. Davies J, St Mary's. A Pioneer Walk Through the Churchyard of St Mary's South Road. St Mary: St Mary's Anglican Church; 1991.

46. Somerset M, Ragless R. St Mary's Walk: A Historical and Social Perspective of a Significant but Little-known Suburb of Adelaide. Mitcham, South Australia: City of Mitcham; 2009.

47. Anson TJ. The Bioarchaeology of the St. Mary's Free Ground Burials: Reconstruction of colonial South Australian lifeways. Adelaide: University of Adelaide; 2004.

48. Nicol R. At the end of the road : government, society and the disposal of human remains in the nineteenth and twentieth centuries. St Leonards, N.S.W. : Allen \&amp; Unwin; 1994.

49. Buikstra JE, Ubelaker DH, Haas J, Aftandilian D, Field Museum of Natural H. Standards for data collection from human skeletal remains : proceedings of a seminar at the Field Museum of Natural History, organized by Jonathan Haas / volume editors, Jane E. Buikstra and Douglas H. Ubelaker, assistant editor, David Aftandilian ; contributions by D. Aftandilian ... [et al.]. Fayetteville, Ark.: Fayetteville, Ark. : Arkansas Archeological Survey; 1994.

50. Mitchell PD, Brickley M. Updated Guidelines for the Standards for Recording Human Remains. Southampton: British Association for Biological Anthropology and Osteology \& Institute of Field Archaeologists; 2017.

51. Brickley M. The Bioarchaeology of Metabolic Bone Disease. Boston: Elsevier Academic Press; 2008.

52. Heron C. Anne L. Grauer (Ed.): A Companion to Paleopathology. Chromatographia. 2013;76(23-24):1795-6. doi: 10.1007/s10337-013-2546-z.

53. Ortner DJ, Butler W, Cafarella J, Milligan L. Evidence of probable scurvy in subadults from archeological sites in North America. American Journal of Physical Anthropology. 2001;114(4):343-51. doi: 10.1002/ajpa.1046.

54. Stuart-Macadam P. Anemia in roman Britain: Poundbury camp. In: Bush H, Zvelebil M, editors. Health in Past Societies: Biocultural Interpretations of Human Skeletal 
Remains in Archaeological Contexts. Oxford: British Archaeological Reserach Series; 1991. p. 101-13.

55. Bruker. Products: http://bruker-microct.com/products/downloads.htm. 2018. Available from: http://bruker-microct.com/products/downloads.htm.

56. ThermoFisher Scientific. 3D Visulaization \& Analysis Software: Amiro-Avizo 2019. Available from: https://www.thermofisher.com/au/en/home/industrial/electronmicroscopy/electron-microscopy-instruments-workflow-solutions/3d-visualizationanalysis-software.html.

57. Colombo A, Ortenzio L, Bertrand B, Coqueugniot H, KnüSel CJ, Kahlon B, et al. Micro-computed tomography of teeth as an alternative way to detect and analyse vitamin D deficiency. Journal of Archaeological Science: Reports. 2019;23:390-5. doi: 10.1016/j.jasrep.2018.11.006.

58. Veselka B, Brickley MB, D'Ortenzio L, Kahlon B, Hoogland MLP, Waters-Rist AL. Micro-CT assessment of dental mineralization defects indicative of vitamin D deficiency in two 17th-19th century Dutch communities. Am J Phys Anthropol. 2019:1-10. Epub 2019/03/19. doi: 10.1002/ajpa.23819. PubMed PMID: 30882907.

59. Brickley M, Buteux S, Adams J, Cherrington R. St. Martin's Uncovered: Investigations in the churchyard of St. Martin's-in- the- Bull Ring, Birmingham, 2001. Oxford: Oxbow Books; 2006.

60. Adams J, Colls K. "Out of the darkness, cometh light' Life and Death in NineteenthCentury Wolverhampton:Excavation of the overflow burial ground of St Peter's Collegiate Church, Wolverhampton 2001-2002. Oxford: BAR Publishing- British Archaeological Reports; 2007.

61. Arabaolaza I, Ponce P, Boylston A. Skeletal Analysis. . In: Adams J, Colls K, editors. 'Out of darkness cometh light' Life and death in Nineteenth-Century Wolverhampton Excavation of the overflow buril ground of St Peter's Collegiate Church, Wolverhampton 2001-2002. Oxford: British Archaeolohical Reports (BAR) Publishing; 2007. p. 39-70.

62. Haines R, Shlomowitz R. Immigration from the United Kingdom to colonial Australia: A statistical analysis. Journal of Australian studies. 1992;16(34):43-52. doi: 10.1080/14443059209387107.

63. Shlomowitz R. Nominated and selected government-assisted immigration from the United Kingdom to Australia, 1848-1900 : annual estimates, by colony. Bedford Park, S. Aust: Flinders University of South Australia, Discipline of Economic History; 1991.

64. Stuart $\square$ Macadam P. Anaemia in Roman Britain. M. BHZ, editor. Oxford: Tempvs Repartatvm; 1991.

65. Atkinson ME, White FH. Principles of Anatomy and Oral Anatomy for Dental Students. Edinburgh: Churchill Livingstone; 1992.

66. Nanci A. Ten Cate's Oral Histology : Development, Structure, and Function. Saint Louis: Saint Louis: Elsevier; 2012.

67. Ioannou S, Henneberg M, Henneberg RJ, Anson T. Diagnosis of Mercurial Teeth in a Possible Case of Congenital Syphilis and Tuberculosis in a 19th Century Child Skeleton. Journal of Anthropology (2010). 2015;2015:1-11. doi: $10.1155 / 2015 / 103842$.

68. South Australian Government. State Records: Registration of Life Events. 2021 [cited 2021 31.03]. Available from: https://archives.sa.gov.au/finding-information/discoverour-collection/registration-life-events/registration-life-events. 
69. Donlon D, Casey M, Haak W, Adler C, Hack W. Early colonial burial practices for perinates at the Parramatta convict hospital, NSW. Australasian Historical Archaeology. 2008;26:71-83.

70. Enlow DH. principles of bone remodeling : an account of post-natal growth and remodeling processes in long bones and the manabile. Springfield, Illinois.: Charles C Thomas; 1963.

71. Kenkre JS, Bassett JHD. The bone remodelling cycle. Annals of Clinical Biochemistry. 2018;55(3):308-27. doi: 10.1177/0004563218759371.

72. Snoddy AME, Buckley HR, Elliott GE, Standen VG, Arriaza BT, Halcrow SE. Macroscopic features of scurvy in human skeletal remains: A literature synthesis and diagnostic guide. American journal of physical anthropology. 2018;167(4):876. doi: 10.1002/ajpa.23699.

73. Stone N, Meister A. Function of ascorbic acid in the conversion of proline to collagen hydroxyproline. Nature. 1962;194:555.

74. Stark RJ. A proposed framework for the study of paleopathological cases of subadult scurvy. International Journal of Paleopathology. 2014;5:18-26. doi: 10.1016/j.ijpp.2014.01.005.

75. Christakos S, Ajibade DV, Dhawan P, Fechner AJ, Mady LJ. Vitamin D: metabolism. Endocrinology and metabolism clinics of North America. 2010;39(2):243. doi: 10.1016/j.ecl.2010.02.002.

76. St-Arnaud R, Arabian A, Travers R, Barletta F, Raval-Pandya M, Chapin K, et al. Deficient Mineralization of Intramembranous Bone in Vitamin D-24-HydroxylaseAblated Mice Is Due to Elevated 1,25-Dihydroxyvitamin D and Not to the Absence of 24,25-Dihydroxyvitamin D1. Endocrinology (Philadelphia). 2000;141(7):2658-66. doi: 10.1210/endo.141.7.7579.

77. Camaschella C. Iron-Deficiency Anemia. N Engl J Med2015. p. 1832-43.

78. Godde K, Hens SM. An epidemiological approach to the analysis of cribra orbitalia as an indicator of health status and mortality in medieval and post-medieval London under a model of parasitic infection. American journal of physical anthropology. 2021. doi: 10.1002/ajpa.24244.

79. Buikstra JE. Ortner's Identification of Pathological Conditions in Human Skeletal Remains. 3 ed. Buikstra JE, editor: Elsevier Science; 2019.

80. Blackwell S, Hendrix PC. Less Common Anemias BEYOND IRON DEFICIENCY. Clinician Reviews. 2001;11(4):56.

81. Ferguson A, Brydon WG, Brian H, Williams A, Mackie MJ. Use of whole gut perfusion to investigate gastrointestinal blood loss in patients with iron deficiency anaemia. Gut. 1996;38(1):120. doi: 10.1136/gut.38.1.120.

82. Jelliffe DB, Blackman V. Bahima disease. Possible "milk anemia" in late childhood. The Journal of pediatrics. 1962;61:774.

83. Weiss G, Goodnough LT. Anemia of Chronic Disease. The New England Journal of Medicine. 2005;352(10):1011-23. doi: 10.1056/NEJMra041809.

84. AlQahtani S. The london atlas: developing an atlas of tooth development and testing its quality and performance measures. ProQuest Dissertations Publishing; 2012.

85. AlQahtani SJ, Hector MP, Liversidge HM. Brief communication: The London atlas of human tooth development and eruption. American Journal of Physical Anthropology. 2010;142(3):481-90. doi: 10.1002/ajpa.21258.

86. Hillson S. Tooth Development in Human Evolution and Bioarchaeology. Cambridge: Cambridge : Cambridge University Press; 2014.

87. Brook AH, Smith JM. Hypoplastic enamel defects and environmental stress in a homogeneous Romano-British population. Eur J Oral Sci. 2006;114:370-4. 
948 88. Nikiforuk G, Fraser D. Etiology of Enamel Hypoplasia and Interglobular Dentin: The Roles of Hypocalcemia and Hypophosphatemia. Metabolic Bone Disease and Related Research. 1979;2(1):17-23. doi: 10.1016/0221-8747(79)90014-6.

89. Seow WK. Developmental defects of enamel and dentine: challenges for basic science research and clinical management.(Report). Australian Dental Journal. 2014;59(s1):143. doi: 10.1111/adj.12104.

90. Brickley MB, D’ortenzio L, Kahlon B, Schattmann A, Ribot I, Raguin E, et al. Ancient Vitamin D Deficiency: Long-Term Trends. Current Anthropology. 2017;58(3):420-7. doi: 10.1086/691683.

91. Brickley MB, Kahlon B, D'Ortenzio L. Using teeth as tools: Investigating the motherinfant dyad and developmental origins of health and disease hypothesis using vitamin D deficiency. American journal of physical anthropology. 2019. doi: 10.1002/ajpa.23947.

92. D’Ortenzio L, Kahlon B, Peacock T, Salahuddin H, Brickley M. The rachitic tooth: Refining the use of interglobular dentine in diagnosing vitamin D deficiency. International Journal of Paleopathology. 2018;22:101-8. doi: 10.1016/j.ijpp.2018.07.001.

93. Mellanby M. Diet and the Teeth: An Experimental Study. Part III. The Effect of Diet on Dental Structure and Disease in Man. Journal of the American Medical Association. 1934;102(18):1523-. doi: 10.1001/jama.1934.02750180075026.

94. Smith PA, Pate FD, Piddock S. These Enchanted Hills: Transforming cultural landscapes in the Adelaide Hills Face Zone, South Australia. Landscape Research. 2020.

95. Jaffe HL. Metabolic, degenerative, and inflammatory diseases of bones and joints. Philadelphia: Philadelphia : Lea \& Febiger; 1972.

96. Fildes VA. Breasts, bottles, and babies : a history of infant feeding. Edinburgh: Edinburgh : Edinburgh University Press; 1986.

97. Lewis M. The Problem of Infant Feeding: The Australian Experience from the MidNineteenth Century to the 1920s. Journal of the History of Medicine and Allied Sciences. 1980;35(2):174. doi: 10.1093/jhmas/XXXV.2.174.

98. Molleson T, Cox M. The Spitalfields Project, Vol. 2: The Anthroplogy, The Middling Sort. York, England.: Council of British Archaeology; 1993.

99. Pate DF, Anson TJ. Stable Isotope And Dietary Composition In The Mid-Late 19th Century Anglican Population, Adelaide, South Australia. Journal Of The Anthropological Society of South Australia. 2012;35(July 2012):1- 16. 


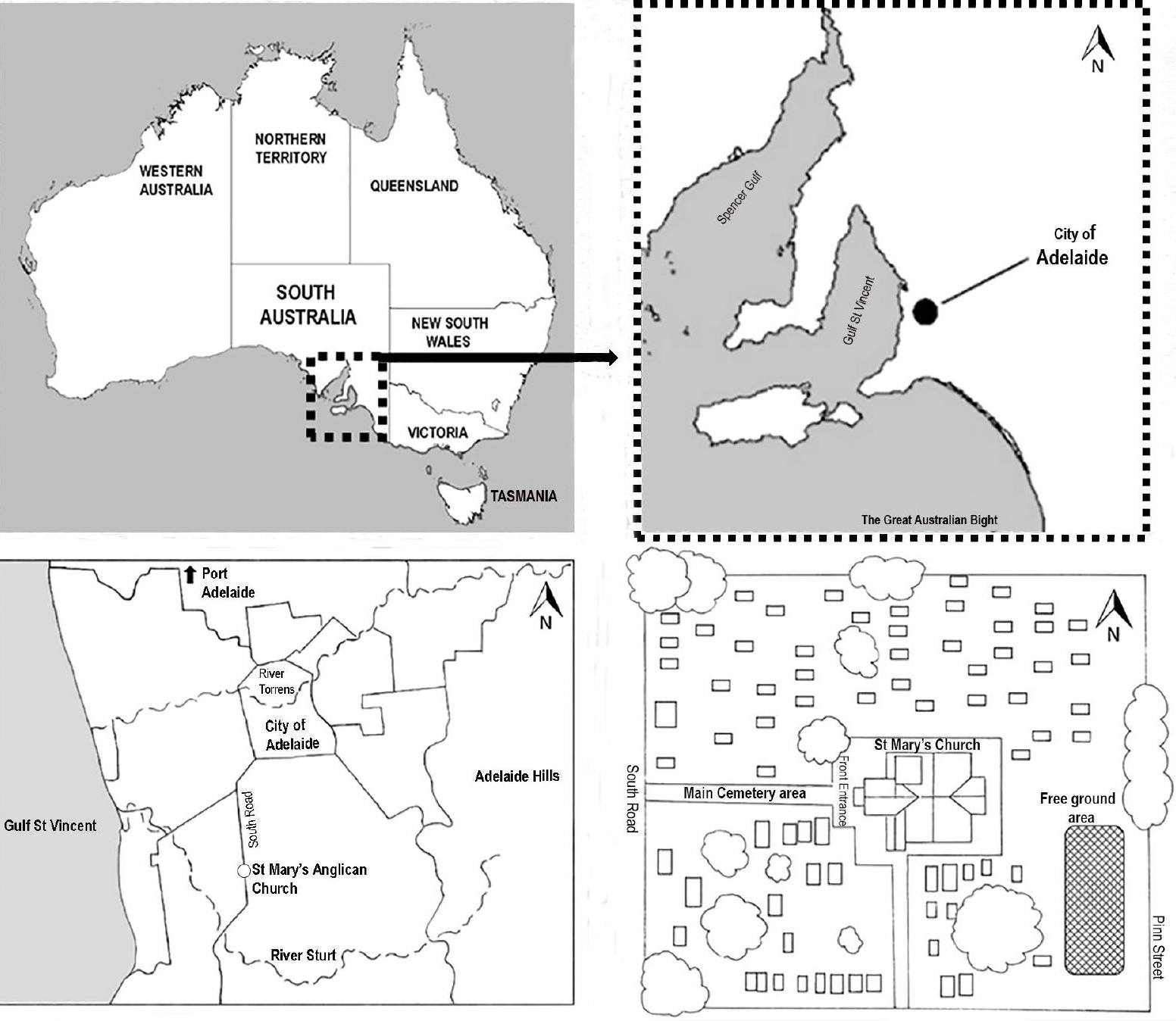




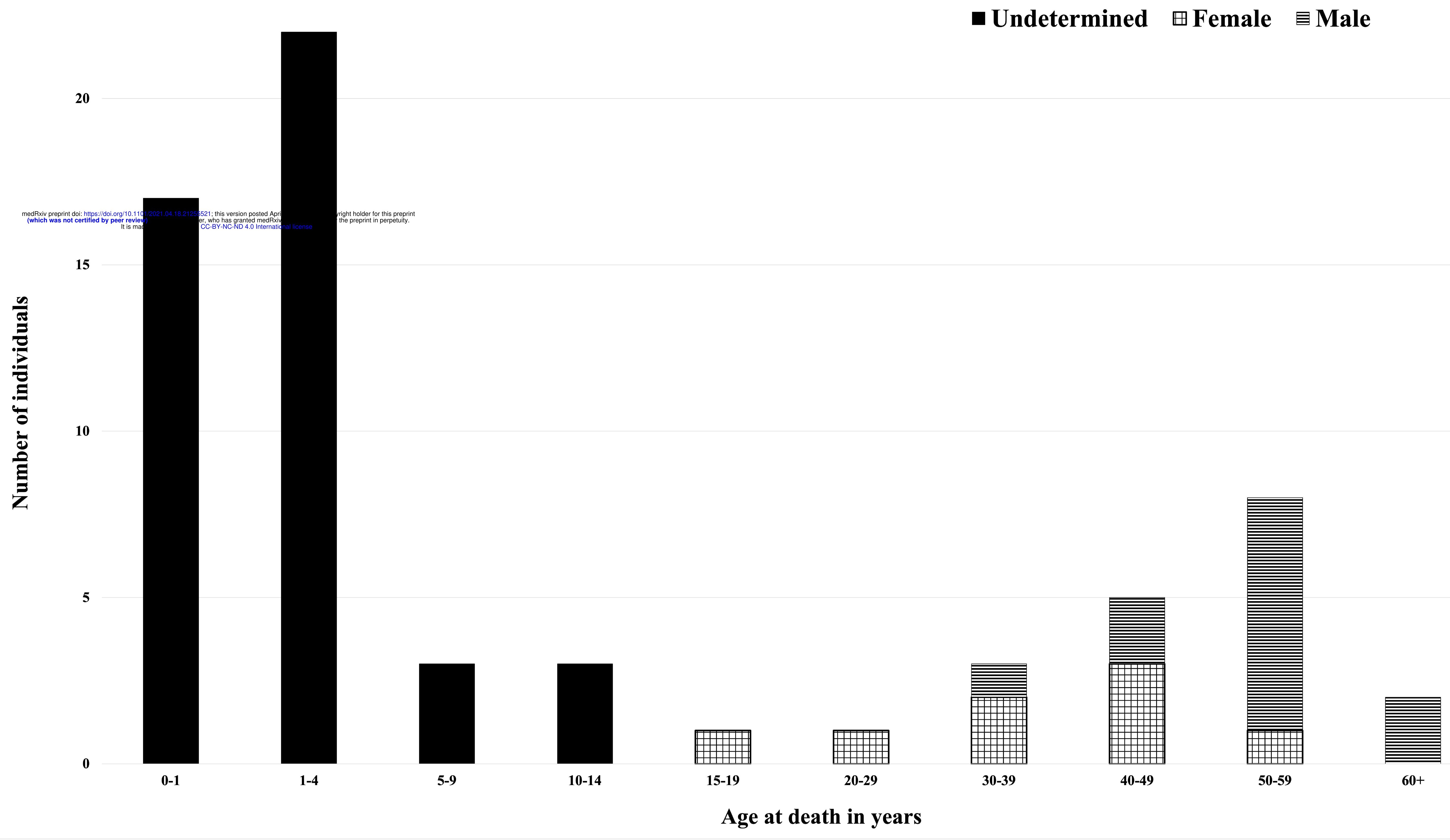




\section{St Mary's Cemetery}

90

$$
\begin{aligned}
& \text { Number of individuals } \\
& \text { provenanced graves }
\end{aligned}
$$

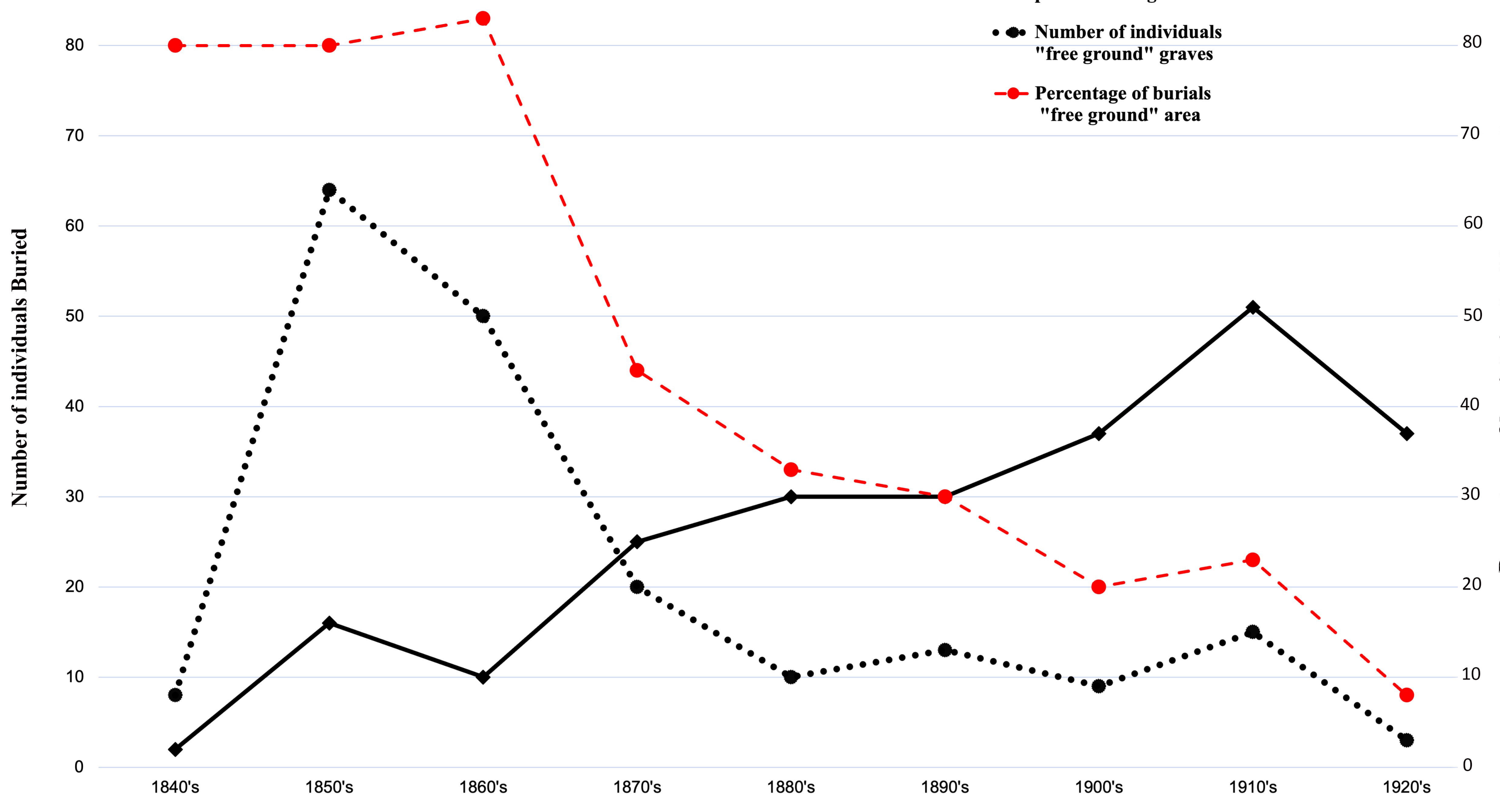




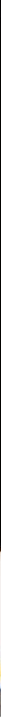




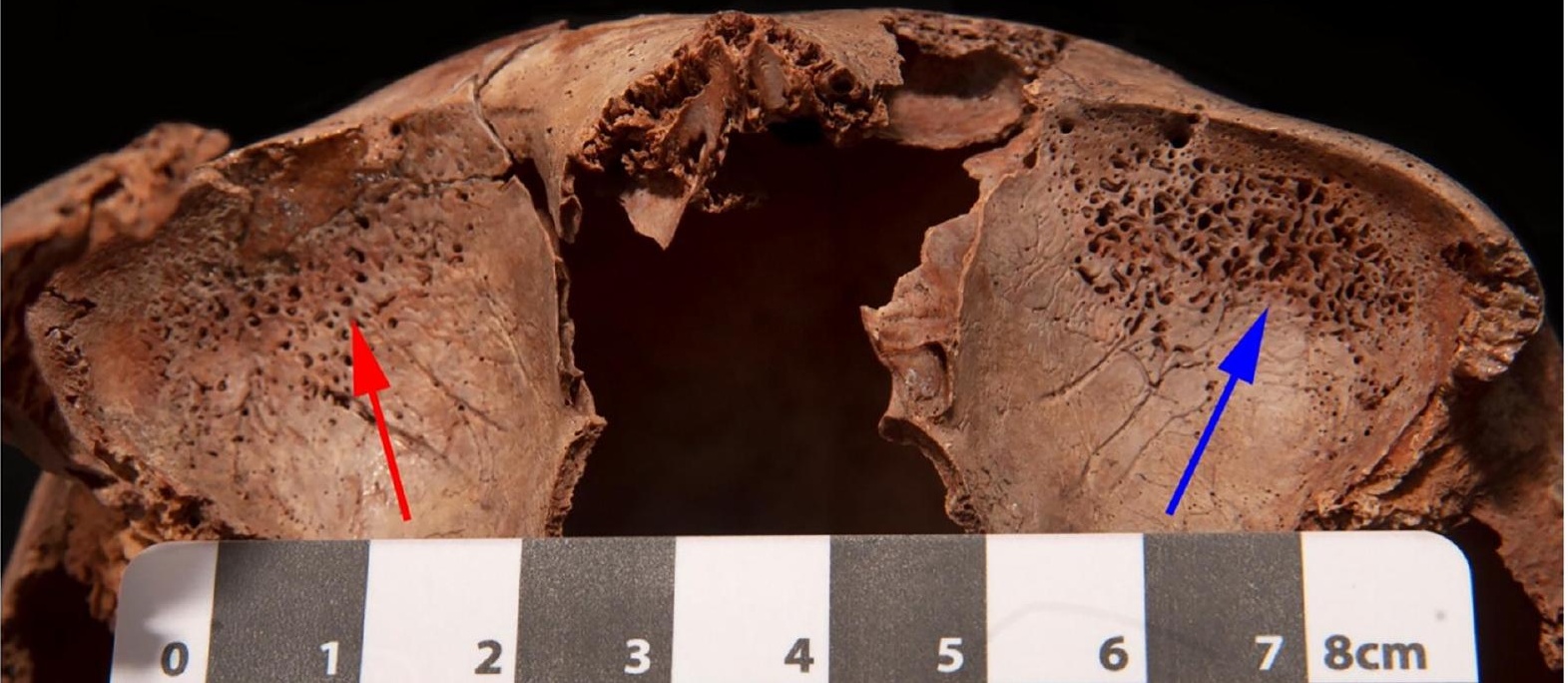




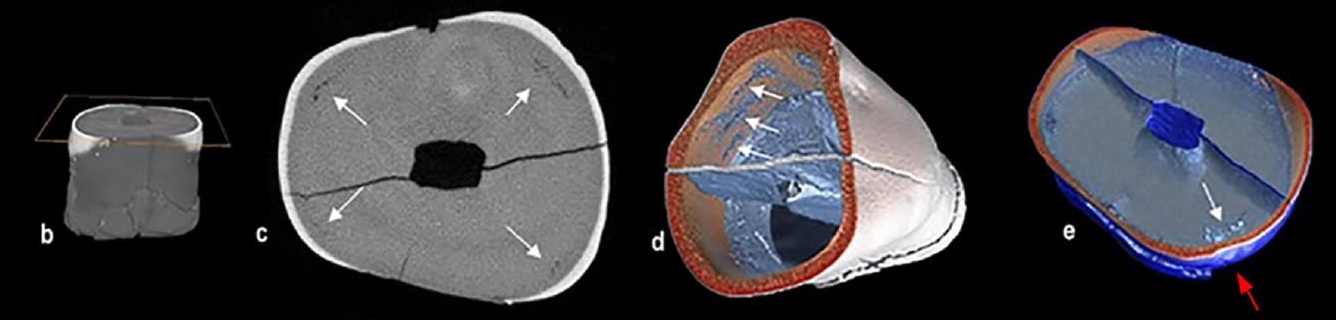


St Mary's

Abnormal porositycortices of bones

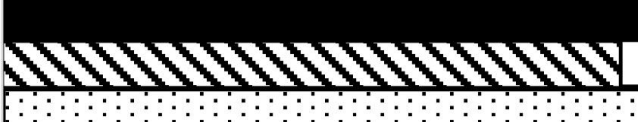

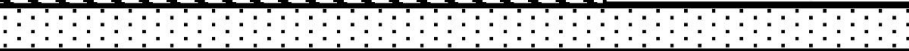

Bending distortion of long bones

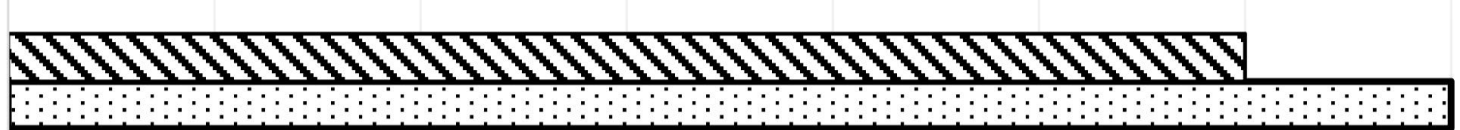

Flarring of costochrondral junctions of ribs

Flarring of metaphyses

Porous lesions of orbital roofs - any "Type 2 to 4"

Porous lesions of orbital roofs - any "Type"

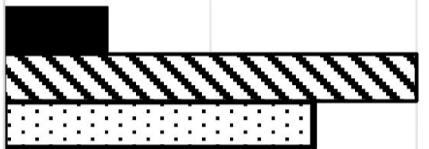

ON1010101010101010110101011010

\section{sing}

